logos_i_ethos_2020_1_(53), s. 141-161

DOI: http://dx.doi.org/10.15633/lie.3693

Roman Konik

https://orcid.org/0000-0002-3715-3540

Uniwersytet Wrocławski

\title{
Projekt malarstwa nowożytnego jako synteza sztuk plastycznych i badań z zakresu filozofii przyrody. Casus Leonarda da Vinci
}

\section{Średniowiecza koncepcja sztuki}

Historia tworzenia obrazów da się podzielić na poszczególne epoki, za którymi stoją stosowane techniki i przypisane im zagadnienia tematyczne. Należy jednak pamiętać, że na kwestie formowania obrazów w poszczególnych epokach wpływała szeroko rozumiana kultura, na którą składały się nie tylko dominanty estetyczne, ale także preferencje ideowe, dominująca filozofia, obowiązująca aksjologia, pewien wpływ miała również nauka. Wszystkie te składniki nadawały obrazom konkretne cele i funkcje.

Aby zrozumieć przełom, który dokonał się w nowożytnym malarstwie, należy w pierwszej kolejności zwrócić uwagę na ogólne twierdzenia dotyczące sztuki w średniowieczu, w szczególności na te, które zostały odrzucone przez artystów renesansowych (nie da się w pełni zrozumieć dokonań twórczych Leonarda da Vinci bez odniesienia do tego, jak sztukę pojmowano w średniowieczu). Sztuki plastyczne okresu średniowiecza (malarstwo freskowe, rzeźba, ilustracje i miniatury, a także mozaiki) podporządkowane były, pomimo pewnego zróżnicowania, dość 
jednolitej estetyce. Podstawowa dominanta estetyczna była pochodną filozofii teocentrycznej, która zakładała pankalię świata, z tego też powodu artyści średniowieczni wierzyli głęboko w to, że piękno transcendentalne jest własnością powszechną bytu (przekonanie to miało z kolei swe korzenie w filozofii platońskiej i plotyńskiej, zostało przeniesione na grunt chrześcijaństwa przez Pseudo-Dionizego i późniejszą scholastykę, która nadała filozofii greckiej nowe znaczenie). Wedle tej ogólnej doktryny piękno świata zmysłowego było tylko odblaskiem piękna nadprzyrodzonego, doskonałego i niedostępnego zmysłom. Z tego też powodu adoracja i upodobanie piękna zmysłowego oderwanego od boskiego Logosu traktowane były nie tylko jako niepotrzebny zbytek, ale wręcz jako szkodliwa pożądliwość zmysłowa (concupiscentia). To przyczyna, dla której malarstwo Wieków Średnich nie stanowiło oddzielnej i autonomicznej specjalności, było podporządkowane architekturze i pełniło wyłącznie element dekoratywny. Każda forma przedstawień obrazowych oderwanych od celów religijnych i dydaktyki pastoralnej traktowana była jako zbędna. W efekcie plastycy średniowieczni zaliczani byli do grupy rzemieślników, w odróżnieniu od tych artystów, którzy wytwarzali sztukę czystą (artes liberales) w oparciu o spekulację intelektualną i koncepcję piękna umysłowego (czyli retorzy, logicy czy architekci). Uformowana w ten sposób struktura funkcji i celów w sztukach plastycznych wpływała bezpośrednio na kwestie formowania obrazu, które podporządkowane było ścisłemu rygorowi celowości: przedstawienie obrazowe miało pełnić rolę wizualnego pomostu $\mathrm{w}$ drodze do niewidzialnej prawdy. Innymi słowy, podstawowym wyznacznikiem wytyczającym ramy sztuk plastycznych było zagadnienie idei wzorcowej, która odnosiła się do idei Boga. W kręgu zainteresowań estetycznych artystów średniowiecza nie znalazły się dążenia do budowania obrazu w oparciu o teorie mimetyczne; każdy przedmiot bądź zdarzenie przedstawiane w obrazach musiało spełniać określony postulat celowości: odsyłać obserwatora do ukrytych znaczeń, które bytują w świecie pozazmysłowym, kierować uwagę obserwatora w obręb zasady sprawczej, którą jest Bóg. Konstrukcja przestrzeni przedstawienia w średniowieczu była też pochodną dominującej filozofii Arystotelesa, który przypisał przestrzeni sześć rodzajów miejsc 
(góra-dół, przód-tył, prawo-lewo) ${ }^{1}$. Takie rozumienie przestrzeni w sztukach plastycznych spowodowało zamknięcie przestrzeni obrazu w dwuwymiarowej klatce, artyście nie wykazywali zainteresowania konstruowaniem iluzji głębi trójwymiarowej w kompozycji obrazu. Z tego też powodu niemal każdy fragment obrazu czy miniatury średniowiecznej może stanowić odrębny obraz, ma formę agregatową (niezależną i statyczną), jest starannie odseparowany. Sztuka obrazowa łacińskiego średniowiecza brała zatem za cel dydaktyczny komentarz nad rzeczywistością widzialną, przypisywała kształtom znaczenia, porządkując tym samym pożądany system relacji. Tak więc głównym celem malarstwa średniowiecznego była przede wszystkim próba ukazania za pomocą graficznych symboli świata metafizycznego, niedostępnego za pomocą zmysłu wzroku. $Z$ tego też powodu malarstwo średniowieczne nie było zainteresowane realizmem anatomicznym, kwestiami związanymi z poprawną implementacją przedmiotów w przestrzeń obrazową; średniowieczny świat sztuk wizualnych odwoływał się do czysto umownych zasad; obraz odbierany był w oparciu o intuicyjno-subiektywne wzorce i sprowadzany do formy ikony (idola), która miała na celu przekierowanie uwagi odbiorcy w świat wyobrażeń pozawidzialnych. System znaczeń wizualnych i ich detekcja były ściśle związane $\mathrm{z}$ arbitralnymi wykładniami pastoralnymi, które niejednokrotnie wychodziły poza zasady prostych skojarzeń. Umberto Eco, tak pisze o tego rodzaju znakach i przypisanych do nich znaczeniach: „[...] w Średniowieczu człowiek żył w świecie zaludnionym znaczeniami, odniesieniami, ukrytymi sensami, Bożymi znakami w rzeczach i w naturze, posługującej się językiem heraldycznym, w którym lew nie był jedynie lwem, orzech tylko orzechem, a hipogryf był tak samo realny, jak lew, ponieważ, podobnie jak on egzystencjalnie był tylko błahym znakiem prawdy wyższej”2. Wypracowane na gruncie filozofii symbole i alegorie zmieniały przedmioty, cechy i ich jakości w pojęcia ogólne, te zaś z kolei, na mocy ustanowienia,

1 Por. Arystoteles, Metafizyka, ks. V. 2010 a, tłum. T. Żeleźniak, Lublin 1996.

2 U. Eco, Sztuka i piękno w Średniowieczu, tłum. A. Olszewski, M. Zabłocka, Kraków 1997, s. 75 . 
przekształcano na język znaków graficznych. Średniowieczna panorama symboli, alegorii i znaczeń była na tyle komplementarna, że niemal każdej rzeczy, przymiotom i cechom przypisywano odpowiedni symbol (często z arbitralnego nadania: jak np. liść dębu - symbol męstwa, liść orzecha - symbol zdrady itd.). Pomimo rozwoju technik malarskich (w średniowieczu malowano głównie na desce, stosując naturalne tempery) oraz nowatorskiego podejścia do fresku, sztuka chrześcijaństwa łacińskiego nie była zainteresowana iluzjonizmem. Obraz odsyłał do pojęć ogólnych i mieścił się w ustalonej hierarchii znaków, gradacja ta obejmowała nie tylko znaki, lecz także kolory, przypisując określonym barwom określone wartości duchowe. W związku z tym stosowano kolory czyste, nie mieszając ich w celu uzyskania efektu światłocienia. Obrazy i freski (a także mozaiki w kościołach wschodnich) wydają się być „płaskie”, dwuwymiarowe, $z$ tego powodu, że sztucznie budowano płaszczyznę kompozycji za pomocą rzutów poziomych opartych na dwóch wymiarach: wysokości i szerokości. Innymi słowy, podział pomiędzy malarstwem Wieków Średnich a sztuką renesansu zbudowany był na prostej polaryzacji: średniowieczny sposób wykonania i odbioru obrazu ufundowany był na ukazaniu rzeczywistości niewidzialnej, zaś renesansowi malarze nadali sztukom plastycznym moc bezpośredniej narracji, która wynikała z nowatorskiego sposobu ujęcia przedmiotu, oddanego w obrazie w taki sposób, w jaki go postrzegamy. Ta zmiana spowodowała, że odmienna była też droga odczytania obrazu - jego odkodowanie nie wymagało znajomości obowiązującej na mocy ustanowienia semantyki; obraz iluzjonistyczny od razu „ujarzmiał” wizualnie obserwatora, podsuwał mu czytelne skojarzenia dekodujące, a jego interpretacja nie była uzależniona od znajomości traktatów przypisujących rzeczom określone wartości. To sprawiało, że średniowieczny symbolizm był systemem zamkniętym i nie wymagał wielkiego kunsztu i ćwiczeń warsztatowych (sztuka średniowiecza spełniała przede wszystkim funkcję sakralną, co renesans przełamywał). Odmienne wymagania stawiało malarstwo nowożytne, które oczekiwało od artystów zupełnie innych kompetencji artystyczno-poznawczych. 


\section{Kognitywizacja sztuk plastycznych i narodziny nowej formy obrazu}

Kto mało myśli, błądzi wiele ${ }^{3}$.

Zmiany, które towarzyszyły formowaniu obrazu na przełomie XIV i XV wieku, były wielopoziomowe i złożone. Radykalna zmiana dotyczy przede wszystkim relacji przedstawianego do tego, co jest przedstawiane. Była ona poprzedzona kwestiami stricte teoretycznymi, które - uogólniając - można określić mianem projektu łączącego naukę z działalnością artystyczną. W konsekwencji zmienia się nie tylko forma obrazu, lecz także rola artysty, który przestaje być wyłącznie rzemieślnikiem i przeistacza się w badacza praw przyrody. Innymi słowy, wraz z narodzinami malarstwa nowożytnego dochodzi do połączenia płaszczyzny stricte artystycznej z naukową ${ }^{4}$.

Wśród licznych teoretyków sztuki tego okresu na szczególną uwagę zasługuje Leonardo da Vinci. Jego wpływ na przekształcenie obrazu w finezyjny komunikat wizualny jest wyjątkowy, ale też niezwykle skomplikowany, trudno bowiem jednoznacznie rozstrzygnąć, czy jego działalność stricte naukowa miała być służebna wobec sztuki, czy też sztuka (jako wizualizacja pewnych idei naukowych) miała pełnić funkcję narzędzia ilustracyjnego, notacji określonych modeli i schematów, a tym samym miała być wtórna i służebna wobec nauki. Jedno jest natomiast pewne - w jego przypadku praktyka artystyczna przeplatała się z płaszczyzną naukową. W związku z tym nowatorstwo w podejściu do malarstwa polegało u Leonarda da Vinci na rozwinięciu wielu problemów malarskich, które wynikały właśnie z postawy badawczej (np. zagadnienia optyczne, badanie światła, cienia, kolorometrii, stosowania perspektywy zbieżnej i powietrznej itd.). Jako filozof przyrody prowadził szereg badań

3 L. da Vinci, Pisma wybrane, tłum. L. Staff, Warszawa 2002, s. 11.

4 Należy pamiętać, że średniowiecze zainicjowano badania przyrodnicze (np. szkoła w Chartres czy szkoła oksfordzka), nabierały one znaczenia w miarę jak upadała filozofia systematyczna, jednak badania te nie były wykorzystywane w świecie sztuki (poza optyką, która miała bezpośrednie przełożenie na formowanie się katedry gotyckiej). 
nad percepcją wzrokową w kontekście różnych zmiennych, takich jak warunki pogodowe czy zmiany natężenia światła w zależności od pory dnia czy roku.

W biografii Leonarda da Vinci w niespotykany sposób przenikała się sfera sztuk plastycznych $\mathrm{z}$ badaniami z zakresu nauk przyrodniczych. Widać to nie tylko w opisach anatomicznych, w pracach z zakresu dendrologii, meteorologii, kartografii, geologii, optyki, lecz także w rozważaniach z zakresu hydrologii czy zoologii. W dorobku badacza znajdujemy zadziwiającą liczbę badań i pozostawionych notatek (przetrwała do dziś, niestety, niewielka ilość). Z notatek i schematów wyłania się naukowiec, który na wzór Arystotelesa chciał za pomocą badań empirycznych stworzyć wszechstronny i syntetyczny wykład na temat praw przyrody. Znaczenie badań empirycznych w jego twórczości było fundamentalne. W notatkach zaznaczał: „Unikaj nauk spekulatywnych, których twierdzenia nie są poparte przez doświadczenie" ${ }^{5}$. Pisma Leonarda niejednokrotnie noszą znamiona spekulacji metaartystycznych, wykraczających poza kwestie stricte estetyczne i praktyczne. Ta tendencja, którą możemy określić mianem kognitywizacji sztuki, jest jedną z fundamentalnych kwestii w zrozumieniu biografii tego artysty. Malarstwo w jego ujęciu wykracza dalece poza sferę rzemiosła: „Malarstwo stawia najpierw swe naukowe i prawdziwe zasady (co to jest ciało zacienione i co to jest cień pierwotny i cień pochodny, i co to jest światło, co to jest ciemność, jasność, barwa, ciało, kształt, położenie, odległość, bliskość, ruch i spoczynek), które dają się pojąć wyłącznie umysłem, bez działania rąk. I to będzie nauka o malarstwie, która pozostaje w umyśle oddającym się tej sztuce, z niej rodzi się potem działanie" ${ }^{\text {. W }}$ Wego mniemaniu niepodobna być artystą bez gruntowej znajomości filozofii przyrody. Sztuki plastyczne, rekonstruując w przestrzeni obrazu świat widzialny, muszą wyjść poza czystą obserwację, która w potocznym mniemaniu wystarcza do tego, by implementować w przestrzeń obrazu to, co postrzega artysta. Wedle teorii Leonarda da Vinci artysta, na wzór antycznego demiurga,

5 L. da Vinci, Pisma wybrane, dz. cyt., s. 27.

6 L. da Vinci, Pisma wybrane, dz. cyt., s. 37. 
musi na nowo w kompozycji plastycznej odtworzyć materię, nadać jej pożądany kształt, zrekonstruować w przestrzeni obrazu przedmiot lub zjawisko. Gwarancją poprawnej rekonstrukcji jest gruntowana wiedza, nie tylko z zakresu jawienia się natury naszym zmysłom, lecz także jej zasad istnienia. Tak więc Traktat o malarstwie jego autorstwa w zupełnie inny sposób definiuje twórcę, jako artystę-naukowca ${ }^{7}$. Jego podstawowym zadaniem jest empiryczne badanie świata przyrody. Taka postawa badacza, uznająca prymat badań nad aktem twórczym, jest czymś zupełnie nowym w historii sztuki. W swych pismach Leonardo niejednokrotnie zaznaczał: „Musisz wpierw opisać teorię, potem praktykę"8. Co prawda, miał on świadomość odmienności celów nauki i sztuki (celem nauki jest szeroko rozumiana użyteczność, zaś sztuki wywoływanie określonych emocji), lecz miał też głębokie przekonanie, że artysta chcący skutecznie i intencjonalnie oddziaływać na odbiorcę musi znać zarówno podstawy nauk biologicznych, psychologii percepcji, jak i skuteczność oddziaływania form obrazowych (ich konstrukcję).

\section{Inspiracje pitagorejskie w szkole florenckiej}

Jednym z najbardziej widocznych przykładów prymatu nauki nad zagadnieniami technicznymi w sztukach plastycznych renesansu jest zastosowanie tzw. costruzzione legittima, czyli matematyczne sformalizowanie i ujęcie przestrzeni widzialnej. Leonardo da Vinci był głęboko świadom tego, że starając się oddać w przedstawieniu graficznym jakąś rzecz lub zdarzenie, należy posiłkować się różnego rodzaju schematami porządkującymi surowy i chaotyczny materiał zmysłowy. Translacja tego, co widzimy, w kompozycję obrazu musiała spełniać przynajmniej trzy postulaty: po pierwsze - być powszechna (uniwersalna), po drugie - niezawodna,

7 Traktat o malarstwie autorstwa Leonarda da Vinci został pośmiertnie zestawiony z jego notatek i po raz pierwszy wydany dopiero w 1651 w Paryżu i Rzymie. Polski przekład, w tłumaczeniu Wojciecha Gersona, został wydany w Warszawie w roku 1876 i był zatytułowany Rozprawa o malarstwie Leonarda da Vinci. Jako Traktat o malarstwie przełożony został ponownie przez Marię Rzeplińską w 1961 roku i wydany w Krakowie.

\footnotetext{
8 L. da Vinci, Pisma wybrane, dz. cyt., s. 27.
} 
po trzecie musiała dawać gwarancję poprawności przekształceń. Renesansowi teoretycy, jako entuzjaści i spadkobiercy antyku, połączyli badania Euklidesa (zastosowanie wiedzy matematycznej w dziedzinie geometrii) z witruwiańskim systemem postrzegania perspektywicznego. Metoda organizacji przestrzeni prekompozycyjnej w obrazie oparta była na zasadach rzutu geometrycznego (perspektywicznego), czyli na tzw. piramidzie widzenia, której wierzchołkiem jest oko ludzkie. Leonardo da Vinici wielokrotnie przekonywał, że poprawne zastosowanie perspektywy geometrycznej do kompozycji obrazowej nie tylko daje rękojmię poprawności transpozycji (zgodnej z naturalnym sposobem widzenia), ale pełni też rolę matematycznego wzorca, który jest gwarancją artystycznej doskonałości. „Praktyka musi być zawsze zbudowana na podstawie dobrej teorii, do której perspektywa jest przewodniczką i bramą i bez niej nie zdziałasz nic dobrego w dziedzinie malarstwa" ${ }^{\prime \prime}$. Leonardo, jako jeden z pierwszych teoretyków, badał malarstwo pod kątem perspektywy zbieżnej, powietrznej, a nawet anamorfotycznej (stosuje się ją dziś w kinematografii). Ten zwrot i docenienie geometrycznych reguł rozpoczęły w historii sztuki swoisty podbój przestrzeni widzialnej, która zmieniła swój dotychczasowy charakter w sztukach plastycznych: nie była już chaotycznym i trudnym zagadnieniem dla artysty, lecz zmieniła się za pomocą aksjomatyki geometrycznej w przestrzeń agregatową, którą da się uporządkować, da się też zadbać o poprawne przeniesienie postrzeganych przedmiotów w przestrzeń obrazu. Leonardowskie przedkładanie zasad geometrycznych nad kwestie techniczno-artystyczne wynikało $\mathrm{z}$ jego nieujarzmionej chęci poznania i zrozumienia zjawisk przyrody za pomocą matematycznego wzorca. $Z$ tego też powodu zastosowanie perspektywy postrzegał $\mathrm{w}$ ramach zdobyczy intelektualnych, siła iluzji skryta w jego obrazach i freskach była poparta silną i niezawodną sankcją matematyczną. Każdy obraz artysty można analizować jako zamknięty system form: da Vinci, chcąc przedstawić portret, rzecz czy zdarzenie, w pierwszej kolejności poddaje kompozycję obrazu sztucznym systemom geometrycznym, pełniącym rolę strukturalnego 
narzędzia porządkującego przestrzeń obrazu, dopiero potem wypełnia je „mentalnymi obrazami”, mając już gwarancję tego, że obraz ma izomorficzne odniesienie do porządku przyrody. Zastosowanie metod rzutu geometrycznego do kompozycji obrazu dało artyście przeświadczenie, że natura zapisana jest w języku matematyki, a tym samym, że stosując w akcie twórczym zasady geometryczne, da się poprawnie odwzorować w malarstwie świat widzialny.

Kolejną kwestią, która charakteryzuje sztukę renesansu, jest kwestia chromatyczna, czyli zastosowanie tzw. metody chiaroscuro (światłocienia). Obraz przedrenesansowy bazował na mocnych i ostrych konturach przedstawianych przedmiotów, wypełnianych kolorami czystymi, co sprawiało, że przedmioty i postacie namalowane w obrazach przesuwały całość kompozycji w kierunku modeli, znaków, schematów graficznych (tak jak współczesne piktogramy). W renesansowym obrazie istotną rolę odgrywało postrzeganie, stąd obraz starał się zbliżyć kompozycję do naturalnego oglądu poprzez realistyczną iluzyjność obrazu. Między innymi na obserwacji zbudowany jest leonardowski trójwymiarowy modelunek przedmiotów, który to stał się cechą charakterystyczną jego twórczości. Jednak zanim został zastosowany w technice malarskiej, został poprzedzony gruntownymi badaniami z zakresu optyki i geometrii. Przy tej okazji warto też pamiętać, że Leonardo da Vinci jako jeden z pierwszych teoretyków wprowadził gradację cieni, rozróżniając między cieniem własnym (ombre originale) i cieniem rzuconym (ombre derivative).

Przypatrując się twórczości malarskiej Leonarda da Vinci, trudno odnaleźć obraz lub fresk, który koncentrowałby się wyłącznie na detalu czy który eksplorowałby jedynie wyodrębniony przedmiot. Artysta był przekonany, że doświadczenie wyobrażeniowe w akcie percepcji obrazu musi być zbliżone do wzrokowego aktu poznania, a więc umiejscowione w przestrzeni jako naturalnej formie bytowania przedmiotu. Proponowana przez Leonarda da Vinci całościowa kompozycja obrazu wiąże akt percepcji wizualnej z przedstawieniem, skłania odbiorcę do poszukiwania analogii, porównań i skojarzeń tego, co widzimy w obrazie, z tym, co oglądamy w naturze. $Z$ tego też powodu obrazy autorstwa Leonarda 
obejmują kompozycyjnie naturalne środowisko, $\mathrm{w}$ tle widzimy drobiazgowo oddany pejzaż, elementy architektury, chmury itd. Tego rodzaju elementy trudno traktować wyłącznie w charakterze tła czy dekoracyjnego dopełnienia, jest to coś znacznie istotniejszego, gdyż w akcie percepcji spaja kompozycję w czytelny przekaz zbliżony do naturalnego oglądu. Leonardo jako jeden z pierwszych artystów prowadził zaawansowane badania dotyczące tła pejzażowego. Badania z zakresu postrzegania przedmiotów dotyczyły również zagadnień ruchu obrotowego przedmiotów ${ }^{10}$, kształtu i widzianych konturów przedmiotu, co zaowocowało wynalazkiem techniki sfumato.

\section{Mona Lisa: od portretu do idealizacji}

Malarstwo Leonarda da Vinci możemy potraktować jako splot naukowej obserwacji natury, znajomości budowy przyrody (jej zasad funkcjonowania) oraz niebywałych zdolności warsztatowych. Jego twórczość plastyczna, w odróżnieniu od średniowiecznych artystów, była dla niego zajęciem stricte intelektualnym, a nie praktycznym (sam pisał w notatkach, że malarstwo to: „una cosa mentale”). Być może $\mathrm{z}$ tego powodu wiele obrazów i rysunków Leonarda nie zostało ukończonych i potraktowanych przez niego jako wyrażenie określonych idei za pomocą notacji graficznej, jako etap prac mających na celu zrozumienie praw natury.

Dorobek artystyczny Leonarda da Vinci kojarzony jest najczęściej z portretem Mona Lisa (zwanym też Gioconda). Portret ten zachwyca nie tylko finezją wykonania, lecz także nowatorskim podejściem do zagadnienia obrazu, uznawany jest wręcz za ikonę nowożytnej sztuki przedstawieniowej. Artysta zanim przystąpił do malowania portretu, sporo uwagi poświęcił kwestiom przygotowawczym, nie tylko w zakresie

\footnotetext{
10 W wielu obrazach Leonarda możemy dostrzec ilustrację wyników badań obejmujących zagadnienia związane z ruchem. Wystarczy przyjrzeć się mediolańskiej Ostatniej wieczerzy. Leonardo podjął się w kompozycji niezwykle trudnego zadania, chciał we fresku przedstawić dramatyczny moment, który zapadł w chwili, w której Chrystus podczas ostatniej wieczerzy wyznaje, że ktoś z siedzących przy stole Go zdradzi. Ten moment jest wizualnym studium psychologii postaci zbudowanym $\mathrm{w}$ teatralnej manierze gestykulacji, napięcia.
} 
szkiców kompozycyjnych, ale także doboru materiałów. Da Vinci w 1503 roku, otrzymując zlecenie na namalowanie szesnastoletniej córki zamożnego kupca florenckiego Antonia di Noldo Gherardiniego, był w trakcie zaawansowanych badań nad zagadnieniem światła. Przed rozpoczęciem malowania portretów wykonał w podziemiach szpitala Santa Maria Nuova szereg sekcji zwłok, w których szczególną uwagę poświęcił mięśniom twarzy. W kręgu jego zainteresowań plastycznych było wizualne przedstawieni emocji za pomocą mimiki twarzy (najbardziej reprezentatywnym dziełem pozostanie tu Ostatnia wieczerza). Malarz zdawał sobie sprawę, że fizjonomia człowieka jest wynikiem odpowiedniej gry mięśni twarzy, które z kolei są efektem odpowiedniego nastroju. W kontekście tego rodzaju badań portret Giocondy miał być notacją graficzną i pochodną studiów nad zagadnieniami optyki. Tego rodzaju podejście widać już w doborze materiału podkładowego: Leonardo wybiera starannie podobrazie $\mathrm{z}$ drewna topoli wyciętej $\mathrm{z}$ wnętrza pnia. Topola w odróżnieniu od lipy czy dębu ma prawie niewidoczne usłojenie i po odpowiednim wypolerowaniu powierzchnia deski przypomina w strukturze i gładkości taflę szkła. Leonardo porzuca też tradycyjne rozwiązania w kwestii zagruntowania deski, nie stosuje mieszanki drobno zmielonego gipsu $\mathrm{z}$ wodą, pokrywa deskę bielą ołowianą, która podobnie jak warstwa srebra w zwierciadle - odbija refleksy świetlne poprzez półprzezroczyste warstwy laserunku ${ }^{11}$. Innymi słowy, światło padające na zamalowaną w specyficzny sposób powierzchnię przechodzi przez farbę, odbijając się od zagruntowanej wcześniej przez biel ołowianą powierzchni i powodując niespotykany efekt „świetlistości” obrazu - wydaje się on jakby podświetlony $\mathrm{z}$ wnętrza światłem odbitym. Ten zabieg potęguje wrażenie trójwymiarowości, zbliżając portret do naturalnego oglądu. W przypadku tego obrazu mamy do czynienia również z nowatorską techniką nakładania pigmentów (artysta jako

11 Doświadczenia materiałowe przeprowadzane przez Leonarda miały też fatalne skutki. Było tak w przypadku fresku Ostatnia wieczerza, w którym artysta zastosował mieszanki farb olejnych nakładanych wprost na ścianę refektarza. Z czasem fresk zaczął się łuszczyć i odchodzić od warstwy tynku. Takie przypadki świadczą jednak o tym, że eksperyment i doświadczenie (nawet nieudane) wyprzedzały u artysty jego działania plastyczne. 
pierwszy dodał do naturalnych składników związki tlenku żelaza i manganu). W całej kompozycji nie widać żadnego pociągnięcia pędzla, nie widać śladu włosia, narzędzie staje się transparentne. W efekcie daje to niebywały modelunek, miękkie przejścia tonalne. Leonardo naturalne barwniki rozpuścił $\mathrm{w}$ oleju $\mathrm{z}$ siemienia lnianego i oleju $\mathrm{z}$ orzecha włoskiego $\mathrm{w}$ takich proporcjach, by kolejne warstwy laserunku przenikały przez siebie, zaś w całości dawały wrażenie przejrzystości i przenikania. Badania rentgenowskie przeprowadzone przez naukowców w 2001 roku wskazują, że twarz namalowanej modelki pokrywa około trzydziestu warstw laserunku ${ }^{12}$. To, co niewidoczne w pierwotnym oglądzie, składa się na wrażenie naturalności, cera Giocondy sprawia wrażenie niemal organicznej. Leonardo, jako badacz, szczególnej uwadze poddał prawa optyki i reakcji ludzkiego oka na światło. $Z$ tego względu omawiany obraz może pełnić rolę pola doświadczalnego; w malarstwie Leonardo ewidentnie stosuje odkryte przez siebie prawidła. W potocznym oglądzie oceniamy wyłącznie niebywałą „naturalność" portretu, nie zdając sobie sprawy $\mathrm{z}$ wiedzy artysty, która przekłada się na sposób malowania. Mało kto potrafi zwrócić uwagę na to, że prawa źrenica Mona Lisy jest nieco większa od lewej. Ustawienie modelki, która sportretowana jest w lekkim skręcie tułowia w pozycji contrapposto, sprawia wrażenie, jakby przed chwilą odwróciła się i spojrzała w stronę odbiorcy, śląc mu zagadkowy i tajemniczy uśmiech. Leonardo wykorzystał w tym przypadku swą wiedzę z zakresu anatomii oka ludzkiego. Jeżeli modelka na chwilę przed przyjętą pozą spoglądała w stronę światła, to uwzględniając wiedzę z zakresu adaptacji oka ludzkiego na światło, źrenica winna być pomniejszona w stosunku do tej, która znajdowała się dalej od źródła światła. Wykonane badania anatomiczne oka i liczne obserwacje pozwoliły artyście uzyskać w portrecie niespotykany efekt $^{13}$. Patrząc na sylwetkę Giocondy, mamy wrażenie, że niezależnie

12 Por. J. M. Greenstein, Leonardo, Mona Lisa and „La Gioconda”. Reviewing the Evidence, „Artibus et Historiae” 25 (2004) no. 50, s. 26.

13 Leonardo da Vinci zalecał, by obserwację natury zacząć od analizy budowy oka, tak by w pierwszej kolejności zrozumieć, jak zbudowane jest narzędzie, za pomocą którego obserwujemy świat. 
od zajmowanej pozycji obserwatora bohaterka obrazu patrzy zawsze wprost w jego oczy. Tajemnica uśmiechu Mona Lisy wydaje się także być pochodną zdobytej uprzednio wiedzy podczas przeprowadzanych sekcji zwłok. Z notatek sporządzanych podczas badań anatomicznych możemy się dowiedzieć, że malarz poświęcił sporo uwagi mięśniom mimicznym twarzy i nerwom, kontrolującym mięśnie. Wielu współczesnych interpretatorów twórczości Leonarda da Vinci widzi w jego postawie pierwowzór lekarza - badacza (podobnie jak w przypadku Andreasa Vesaliusa). Jednak Leonardowskim badaniom anatomicznym przyświecały inne intencje - artystę interesował przede wszystkim człowiek jako spójna konstrukcja i mechanizm. Z tego powodu badania, które wykonywał, miały za cel poszukiwanie pewnych prawidłowości anatomicznych i stąd często noszą one znamiona badań porównawczych, których wyniki mogły być potem wykorzystane w pracach plastycznych. Artysta poświęcił wiele uwagi budowie anatomicznej czaszki. Jego skrupulatne opisy gardła, krtani, nerwów czaszkowych i rdzeniowych, nosa, mięśni twarzy miały na celu odszyfrowanie skrytych w narządach mechanizmów odpowiedzialnych za mimikę twarzy, czyli de facto za wyrażanie emocji. Jak zauważa Charles Imperatori, tylko ktoś, kto poznał drobiazgowe działanie mięśnia okrężnego ust, mógł namalować taki uśmiech, jak w przypadku portretu Mona Lisy ${ }^{14}$.

Leonardo jako badacz, oprócz szczegółowych opisów z przeprowadzanych badań, wykonał wiele rysunków anatomicznych, ilustrując zdobytą wiedzę schematami. Wiedza ta została wykorzystana później w kształtowaniu fizjonomii malowanych postaci, potwierdzają to liczne przykłady z biografii artysty. Świadczy o tym chociażby fakt, że omawiany tu portret Giocondy artysta malował w fazie wstępnej, korzystając z modelki, potem zaś przez szesnaście lat wykańczał go w oparciu o liczne schematy i notatki. Tego obrazu nigdy jednak nie skończył, ale domyślać się możemy, że z czasem twarz modelki zaczęła ewaluować w stronę idealizacji, oddalając się od pierwowzoru. Dla Leonarda ważniejsze było

14 Por. Ch. J. Imperatori, Leonardo da Vinci's contribution to laryngology, rhinology and phonetics, „Ann Otol Rhinol Laryngology” 50 (1941) issue 4, s. 986. 
przekazanie zdobytej wiedzy niż ukazanie podobieństwa do modelki (wystarczy porównać wstępne rysunki, by dostrzec, w jaki sposób przebiegał proces idealizacji przedstawienia). Podobnie było w przypadku obrazu Święty Hieronim na pustyni. Obrazu tego artysta nigdy nie ukończył, po latach dodawał jedynie liczne korekty, które były pochodną jego odkryć anatomicznych (np. dotyczących budowy krtani). Innymi słowy, wszystkie korekty i wykończenia prac Leonarda da Vinci były składową jego talentu i pracy, w której wykorzystywał zdobytą wiedzę.

\section{Badania nad perspektywą}

Kolejną kwestią, na którą warto zwrócić uwagę w twórczości Leonarda da Vinci, jest jego wnikliwa obserwacja percepcji wizualnej z uwzględnieniem różnego rodzaju czynników, które na nią wpływają. Artysta, podobnie jak jemu współcześni malarze florenccy, znał i stosował w obrazach zasady perspektywy zbieżnej. Jednak po wnikliwych badaniach $\mathrm{z}$ zakresu widzialności uznał, że akt percepcji odbywa się zawsze $\mathrm{w}$ zmiennych warunkach powietrznych, a to $\mathrm{z}$ kolei ma wpływ na to, co finalnie postrzegamy. Jako jeden z pierwszych badaczy opisał on i zastosował zasady tzw. perspektywy powietrznej. Zadanie to było o tyle trudne, że perspektywy powietrznej, w odróżnieniu od perspektywy zbieżnej, nie dało się opisać w języku matematyki za pomocą aksjomatów geometrycznych. W związku z tym Leonardo przyjął zasadę czysto opisową. W wyniku licznych eksperymentów wykazał, że w zależności od wilgotności powietrza oraz od jego ilości (czyli odległości od obserwowanego przedmiotu) obiekt zmienia chromatykę w zakresie tonów i nasycenia barw. Badania te wpłynęły znacząco na zwiększenie technik iluzyjnych w obrazach. Jak w większości przypadków, tak też i tutaj, artysta dokonał przełożenie zdobytej wiedzy na stosowane techniki malarskie. Oddalony pejzaż w tle, wychodząc spod pędzla Leonarda, doskonale wizualizuje to, co badacz opisał w notatkach: proporcjonalnie od oddalenia przedmiotów od obserwatora zwiększa się ilość powietrza, które w efekcie pozbawia przedmiot jaskrawości kolorów, jego tony i barwy blakną, przechodząc w widmo koloru niebieskiego. 
Kolejną obserwacją, którą poczynił badacz, jest to, że naturalny akt postrzegania nie wyróżnia przedmiotów poprzez ostre kontury. Co więcej, kontury przedmiotów tracą na ostrości wraz z oddaleniem. Przekładając język optyki na malarstwo, Leonardo da Vinci stosuje technikę zwaną sfumato (wł. zadymiony). Zwracając uwagę na postrzeganie linii krawędzi oddzielających przedmiot od otoczenia, zaobserwował, że ludzkie oko widzi przedmioty zawsze wtopione w tło, zaś krawędź postrzeganego przedmiotu jest lekko rozmyta. Zastosowanie tej wiedzy w technice malarskiej spowodowało, że jego obrazy w sposób niezwykły zbliżają się do obserwacji zjawiska naturalnego.

Da Vinci pod koniec XV wieku (od 1490 roku) pracował nad traktatem na temat światła. Obserwując przestrzeń o różnych porach dnia i roku, formułował pierwsze zasady zależności cienia od światła, rozróżniając światło na bezpośrednie i pochodne (odbite). Światło i cień, wedle badacza, jest pierwszą przyczyną poznawania kształtów przedmiotów, stąd też każda próba oddania przedmiotu w kompozycji obrazu winna być poprzedzona wnikliwymi badaniami z zakresu optyki. Dlatego też jedna z głównych hipotez badawczych widoczna jest niemal w każdej pracy artysty: $w$ jego obrazach światło i cień finezyjnie przenikają się, nie ma wyraźnych granic konturowych pomiędzy nimi.

Ostatnim przykładem pokazującym silny związek malarstwa z nauką jest odwoływanie się przez artystę do własnych badań w zakresie dendrologii. By zrozumieć i opisać biometryczne prawo przyrostu drzew, posiłkował się schematem graficznym drzewa, czyli wizualnym fantomem drzewa, na który składały się tylko te części, które są w obserwowanych drzewach jednego gatunku powtarzalne. Wiedza ta była jego zdaniem konieczna w pracy malarza, gdyż uważał, że w pierwszej kolejności należy poznać główną zasadę budowy całego gatunku, by potem $\mathrm{w}$ akcie kreacji wyposażyć graficzny schemat w poszczególne atrybuty. Tego rodzaju schematy były w przypadku sztuki Leonardowskiej oparte na prostych wykresach i stanowiły geometryczny kościec późniejszych prób plastycznych. Tym samym Leonardo da Vinci dawał dowód na to, że malowanie jest zajęciem stricte konceptualnym, a nie wyłącznie rzemiosłem mającym na celu przeniesienie tego, co się widzi, w przestrzeń obrazu. 


\section{Filozofia przyrody Leonarda da Vinci}

Teoretyczny namysł nad budową i jawieniem się naszym zmysłom natury miał bezpośrednie odzwierciedlenie w warsztacie twórczym Leonarda da Vinci. W pewnym sensie cała działalność artystyczna renesansowego artysty może być postrzegana jako specyficzna realizacja głównych założeń filozofii przyrody. To, co nowatorskie w ujęciu leonardowskim to, w pewnym sensie, zerwanie z tradycją platońską i arystotelesowską (w zakresie wizji filozofii przyrody). Począwszy od Leonarda da Vinci zarówno obserwacja, jak i eksperyment, a także szersze wykorzystanie matematyki jest tym, co funduje nowe spojrzenie na formę obrazu pod względem warsztatu i kompozycji. W pewnym zakresie postawa teoretyczna Leonarda da Vinci jest antycypacją i zalążkiem późniejszej praktyki laboratoryjnej i ekperymentalizmu (od Franciszka Bacona, Roberta Grosseteste'a po Iana Hackinga). Leonardo da Vinci w zupełnie nowatorski sposób starał się uchwycić naturę i istotę eksperymentu. Tym samym Leonardo zrywa $z$ wizją ufundowaną w średniowieczu, wedle której działalność artystyczna była pochodną praktyki teoretycznej, zaś wszelka działalność na gruncie eksperymentu (o ile była ona w ogóle uwzględniana) prowadzona była wyłącznie w celu potwierdzenia zgodności teorii z rzeczywistością. Leonardo jako jeden z pierwszych teoretyków docenił rolę eksperymentu i obserwacji natury (liczne wykresy wirów wody, badania z zakresu meteorologii, które miały tłumaczyć zmienność barw w zależności od odległości obserwatora, eksperymenty botaniczne itd.), tym samym wyznaczając praktyce eksperymentalnej zupełnie inny cel niż dotychczas, czyli nie tyle potwierdzenia zgodności z obowiązującą teorią, ile jej weryfikację. Leonardo ponadto sam kreuje pewne zjawiska w celu ich obserwacji, opisu i zrozumienia. Buduje minilaboratoria, aby prowadzić badania nad naturą wody; konstruując określone aparatury badawcze wyznacza ściśle zakres badań, stawia pytania, formułuje hipotezy badawcze w oparciu o zdobytą w ramach eksperymentu wiedzę, stara się stosować wyniki badań w późniejszej kompozycji obrazu. Szczególnie warto zwrócić uwagę na Leonardowskie badania z zakresu anatomii. Florencki teoretyk prowadzi jako pierwszy badania stricte laboratoryjne, 
opisuje po raz pierwszy określone własności i związki (np. prace nad komorami serca, rytmem zatokowym itd.), w pracach laboratoryjnych wykorzystuje określoną aparaturę badawczą, co więcej, stara się budować odpowiedni model badawczy w taki sposób, by był on wyizolowany i niezależny od zakłóceń (np. wypreparowany odlew mózgu). Jego głównym celem badawczym było pogłębienie wiedzy na temat budowy i funkcjonowania ciała ludzkiego, a to z kolei pozwalało mu przełożyć wyniki badań eksperymentalnych na język sztuki. Wnikliwe studia nad budową natury (np. z zakresu anatomii czy dendrologii) noszą często znamiona refleksji nad wyglądem (jawieniem się obserwowanych rzeczy), czyli nad formą przybraną w wyniku rozwoju i wzrostu. Jednak badania te nie koncentrują się wyłącznie na zagadnieniach stricte materialnych, Leonardo stara się zrozumieć zasadę fundującą formę (jak choćby w badaniach z zakresu fizjonomii). Jego badanie praw natury rozpoczyna się od obserwacji i eksperymentu mającego określić zagadnienie elementarnych składników materii, to z kolei prowadzi go do badań w zakresie prawidłowości zachodzących w przyrodzie, zagadnień przyczynowości, matematyczności przyrody, zagadnień związanych z ruchem i jego przyczynami, sposobów jawienia się podmiotowi poznającemu. Wszystkie wymienione elementy wskazują na fundamentalną rolę obserwacji i eksperymentu w tworzeniu obrazu.

\section{Zakończenie}

Cała działalność zarówno naukowa, jak i artystyczna Leonarda da Vinci wpisuje się w renesansowy spór o współzawodnictwo wśród sztuk plastycznych. Korona pierwszeństwa, wedle Leonarda, należy się malarstwu, jako najbardziej unaukowionej dziedzinie sztuk plastycznych. Artysta uważał, że malarstwo jest ukoronowaniem sztuk jako takich, gdyż dzięki silnemu związkowi z badaniem praw przyrody i stosowaniem reguł geometrycznych malarz jest w stanie uformować obraz, który przekaże całe bogactwo świata i umysłu ludzkiego.

Rozważania tego rodzaju, oprócz walorów historyczno-poznawczych, mogą dziś stanowić cenny komentarz do swoistego pęknięcia w świecie 
nauki i podziału na nauki humanistyczne i pozostałe. Casus Leonarda da Vinci może być przykładem łączenia badań stricte naukowych z działalnością artystyczną, integrując tym samym, tak dalece wydawałoby się, odległe płaszczyzny aktywności.

Jeżeli nawet zgodzimy się z zarzutem, że badania Leonarda były chaotyczne i mocno rozproszone, a w efekcie nieskodyfikowane i pozbawione syntezy zdobytej wiedzy na temat obrazowania, to jednak musimy uznać, że jego działalność naukowa (w zakresie visual studies) pozwoliła na stworzenie siatki pojęć quasi-epistemologicznych mających na celu opisanie i zbadanie fenomenu malarstwa iluzyjnego. To, co istotne u progu malarstwa nowożytnego, to silne przekonanie, że tworzenie malarstwa iluzyjnego winno być oparte zarówno na umiejętnościach warsztatowych, jak i na obserwacji natury i poznaniu jej zasad. Pogłębiona refleksja oparta na badaniach empirycznych i obserwacji powinna wyprzedzać wszelkie działania w zakresie plastyki.

Jako podsumowanie niniejszych rozważań niech posłuży fragment z zapisków artysty, ukazujący silny związek malarstwa z filozofią: „Kto nie kocha malarstwa, nie kocha filozofii i natury. Jeśli będziesz gardził malarstwem, które jest jedynym naśladowcą wszystkich widzialnych dzieł natury, zaprawdę gardzić będziesz subtelnym wynalazkiem, który z filozoficzną i bystrą rozwagą bada wszystkie jakości kształtów, tło, miejsce, drzewa, zwierzęta, rośliny i kwiaty, otoczone światłością i cieniem. I zaprawdę jest to nauka i prawowita córka natury, gdyż malarstwo zrodzone jest $\mathrm{z}$ natury. [...] Zbadaj zatem wiedzę, potem weź się do praktyki, zrodzonej z tej wiedzy"15.

\section{Bibliografia}

Arystoteles, Metafizyka, t. 3, tłum. T. Żeleźnik, Lublin 1996.

Bongioanni F. M., Leonardo da Vinci pensatore, Piacenza 1935.

Eco U., Sztuka i piękno w Średniowieczu, tłum. A. Olszewski, M. Zabłocka, Kraków 1997. 
Gentile G., Il pensiero di Leonardo da Vinci, Firenze 1941.

Greenstein J. M., Leonardo, Mona Lisa and „La Gioconda”. Reviewing the Evidence, „Artibus et Historiae" 25 (2004) no. 50, s. 17-38.

Imperatori Ch. J., Leonardo da Vincis contribution to laryngology, rhinology and phonetics, „Ann Otol Rhinol Laryngology” 50 (1941) issue 4, s. 983-986.

Saitta G., Il pensiero italiano nell'Umanesimo e nel Rinascimento, vol. 2-3, Bolonia 19501951, 1961.

Swieżawski S., Między średniowieczem a czasami nowymi, Warszawa 1983.

Vasari G., Żywoty najsławniejszych malarzy, rzeźbiarzy i architektów, wybór, oprac.

K. Estreicher, Warszawa 1979.

Verga E., Bibliografia vinciana, Bolonia 1931.

da Vinci L., Pisma wybrane, tłum. L. Staff, Warszawa 2002.

da Vinci L., I manoscritti e i disegni di L. da Vinci, vol. 1: Il Codice Arundel 263, I-IV, R 1923-1930; vol. 2: Il Codice A2172, Roma 1936.

da Vinci L., I fogli mancanti al codice di Leonardo da Vinci su'l volo degli uccelli nella Biblioteca Reale di Torino, a cura di E. Carusi, Roma 1926.

da Vinci L., Frammenti letterari e filosofici, a cura di E. Solmi, Firenze 1979. da Vinci L., Tutti gli scritti, a cura di A. Marinoni, Milano 1952.

\section{Abstrakt}

Początek malarstwa nowożytnego wiąże się z nową koncepcją obrazu, głównie dzięki zastosowaniu nowych metod kompozycji konstruowanej w oparciu o zasady perspektywy zbieżnej i światłocienia. Należy jednak pamiętać, że zastosowanie nowatorskich technik budowy obrazu nie ograniczało się wyłącznie do zmian kompozycyjnych w obszarze formowania struktury obrazu, lecz dotyczyło przede wszystkim zastosowania zupełnie odmiennego podejścia do aktu twórczego. Dlatego też propozycje renesansowych artystów wykraczają dalece poza kwestie warsztatowe i redefiniują dotychczasową relację reprezentowania przedmiotu w obrazie. W nowatorskiej formule zmienia się zatem funkcja i cel malarstwa. W Traktacie o malarstwie Leonardo da Vinci przekonuje, że akt poznania winien wyprzedzać akt tworzenia. Jeżeli celem nowego malarstwa ma być wierne oddanie kształtów materii, należy przede wszystkim poznać reguły, wedle których skonstruowany jest świat widzialny. $Z$ tego też powodu renesansowa wizja implementacji natury w świat znaków graficznych bierze swój początek w akcie 
poznawczym, czyli w rozpoznaniu prawideł budowy świata materialnego. Poszukiwanie cech istotowych, eliminacja tego, co przypadkowe i jednostkowe na rzecz ogólnych prawideł, wiązały się określoną wiedzą, która później miała zastosowanie w „odtworzeniu” tego, co zaobserwowane w przestrzeni obrazu. Artysta, wedle Leonarda da Vinci, miał się stać przede wszystkim badaczem przyrody, by potem na wzór antycznego Demiurga, z niekształtnej materii uformować na nowo świat przedmiotów. Przesunięcie akcentów w akcie twórczym ( $\mathrm{z}$ tworzenia symboli graficznych na rzecz mimetycznego podobieństwa do świata postrzeganego) wynikało z przekonania, że zastosowanie prawideł matematycznych (perspektywa zbieżna) i fizykalno-optycznych (reguły chromatyki) pozostaje narzędziem prawomocnego poznania świata natury. Renesans, wprowadzając w kompozycję obrazu perspektywę rzutu środkowego, wypracował nowatorskie reguły przedstawiania przestrzeni trójwymiarowej na dwuwymiarowej powierzchni. Od czasu renesansu zasada ta została powszechnie przyjęta jako narzędzie racjonalnej rekonstrukcji rzeczywistości widzialnej. Opisana i zastosowana autonomia poznania artystycznego w malarstwie nowożytnym wprowadza nową jakość w relację wzoru i jego graficznego odwzorowywania. Materialny nośnik, którym pozostaje obraz, u Leonarda da Vinci przybiera formę notacji tego, co za pomocą reguł geometrycznych zostało odkryte w przyrodzie. Leonardo da Vinci w obserwacji i badaniu przyrody oraz w zastosowaniu geometrii widzi gwarant prawomocności wydobycia piękna $\mathrm{z}$ natury. Tak ustawiona struktura aktu twórczego sytuuje artystę malarza w gronie badaczy prawideł natury, filozofów przyrody, przełamując średniowieczną tradycję zaliczającą plastyków do grona rzemieślników, których trud pracy zaliczany był do grupy sztuk pospolitych (artes vulgares). Leonardo da Vinci, w Codex Urbinas latinas daje wyraz temu, że akt malowania związany jest bezpośrednio z myślą, za którą stoi akt poznawczy, dlatego artysta pracuje najpierw umysłem, a dopiero potem dłońmi.

\section{Słowa kluczowe}

malarstwo, estetyka, filozofia przyrody, psychologia percepcji, historia sztuki, filozofia sztuki, renesans 


\section{Abstract \\ Project of modern painting as a synthesis of fine arts and research in the field of natural philosophy. The case of Leonardo da Vinci}

The very idea that painting in a picture could be a recognizable representation of nature is quite a philosophical issue. It assumes an in-depth knowledge not only of nature itself but also of the principles of knowing it. The entire scientific and artistic activity of Leonardo da Vinci was associated with an attempt to extract from the visible nature something similar to a graphic scheme, so universal that a given class of objects could be represented in the general scheme. A general scheme (or graphic universality) should be understood here as the graphic skeleton of things, a kind of scaffolding which, during the creation of the image, could have been equipped with particular graphic attributes. This predilection to capture the world of nature in a schematic view allowed us to capture and embrace the multitude of objects, the infinite variety of the appearance of things, was an attempt to control the chaotic world of nature. The most important issue that he brings at the threshold of modern painting by Da Vinci is the strong belief that the creation of illusionist painting is conditioned not only by talent but above all by in-depth knowledge of the secrets of nature. This in-depth reflection based on empirical research and observation is to anticipate all artistic activities.

\section{Keywords}

painting, aesthetics, philosophy of nature, psychology of perception, history of art, philosophy of art, Renaissance 